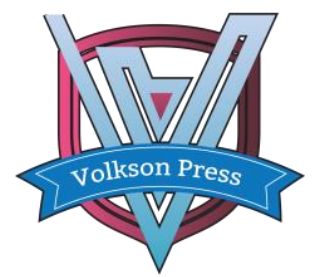

Contents List available at VOLKSON PRESS

Economics \& Management Innovations(EMI)

DOI : http://doi.org/10.26480/icemi.01.2017.349.350

\title{
FDI and economic growth of China
}

\section{Huating $\mathrm{Li}^{1}{ }^{*}$, Ying Wang ${ }^{2}$}

${ }^{1}$ Nanjing University of Finance and Economics Hongshan College, Nanjing, China.

2Nanjing University of Finance and Economics, Nanjing, China.

*Lihuating1206@163.com

This is an open access article distributed under the Creative Commons Attribution License, which permits unrestricted use, distribution, and reproduction in any medium, provided the original work is properly cited.

\section{ARTICLE DETAILS}

\section{Article History:}

Received 02 october 2017

Accepted 06 october 2017

Available online 11 october 2017

Keywords:

FDI; domestic investment; human

capital; economic growth.

\section{ABSTRACT}

This paper analyzes the influence of FDI, domestic investment and human capital on China 's economic growth by using the the function of Cobb-Douglas production model of effective labor. This paper first uses the national data since 1997 to carry on the empirical return. After obtaining the basic results, the author takes Jiangsu Province as an example to carry on the verification analysis. It is shown that, the role of human capital in economic promotion is greater than that of domestic capital and FDI in general, and the effect of different factors is different in different provinces because of their different endowment differences and industrial structure.

\section{Introduction}

Foreign direct investment (FDI) has become a common phenomenon in the global economy. Domestic and foreign scholars have conducted indepth research on the relationship between FDI and economic growth. Balasubramanyam et al.'s study shows that FDI has a greater effect on the economic growth of countries that implement export-oriented policies than FDI countries that implement import substitution policies, and FDI output elasticity is much greater than the output elasticity of domestic investment in these countries. Boreasetein et al. Analyzed the foreign investment of 69 developing countries from 1970 to 1989 by using the endogenous growth model. The results show that FDI has effectively promoted the transfer of production technology from industrial countries to developing countries. Compared with domestic investment, FDI But also to promote economic development. Laura Alfaro et al. Used the crosscountry data from 1975 to 1998 to analyze the conclusion that countries with perfect financial markets benefited from FDI and proposed a method to calculate the net effect of FDI on a country's economic development.

From the recent domestic literature, Shen Kunrong and others through the construction of FDI and human capital endogenous growth model for empirical analysis, the results show that the growth of FDI leads to economic growth, and the degree of diffusion of FDI technology plays an important role in human capital level.Jiang Jinfan's theoretical analysis and empirical analysis show that FDI has a capital effect and spillover effect in China's economic growth, and makes a reasonable explanation of the mechanism of capital effect and spillover effect of FDI.

This paper draws on the regression model of Shivas. Makki \& Agapi Somwap, examines the direct effect of FDI on China's economic growth and the impact of FDI and human capital and domestic investment on China's economic growth from a new perspective. Taking Jiangsu province as example. Finally, the relevant conclusions and revelation are obtained.

\section{Variable definition and regression model design}

\subsection{Model settings}

In order to study the relationship between FDI and China's economic growth, this paper adopts the Cobb-Grasse production function model, which is an effective labor model.

$$
Y_{t}=A_{t} K_{t}^{\alpha} H_{t}^{1-\alpha}
$$

Where Yt is the output of $t$ year, expressed by gross domestic product (GDP), At represents the system, environment and other factors that can not be observed. Kt is the material capital stock of year $t$, and Ht is the

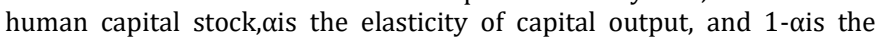
elasticity of human capital output.

Because this paper studies the relationship between FDI and economic growth, the capital stock is divided into FDI and domestic capital, so that FDI can be analyzed as an independent variable and GDP.FDI uses symbolic FDI to indicate that domestic capital Symbol KD, then the total capital $\mathrm{K}$ can be expressed as a mathematical formula:

$$
K_{t}=K D_{t}^{\beta} F D I_{t}^{1-\beta}
$$

Where $K_{t}$ is the material capital stock of year t, $K D_{t}$ is the domestic capital stock of year t, FDI $t$ is the stock of FDI capital for year T. $\beta$ is the weight of domestic capital in total capital composition, 1- $\beta$ is FDI in total capital composition the weight.

In this paper, the human capital is divided into two parts, part of the general labor force, with $\mathrm{L}$ said that the other part of the workers themselves accumulated and investment in human capital stock, the overall mathematical expression:

$$
H_{t}=e^{\lambda} H_{t}^{\prime} L_{t}
$$

Where ${ }^{\lambda} H_{t}^{\prime}$ is the level of education in society as a whole, and the method of years of education is used to measure the human capital situation of society as a whole from an investment perspective.

$$
H^{\prime} t=\Sigma H E_{i t} \bullet h_{i}(\text { ifrom } 1 \text { to } 5)
$$

Where equation (4) is expressed as the total stock of human capital in the whole year, $H E_{i t}$ is the total number of the diploma in the year, and $h_{i}$ is the number of years of education. $\lambda$ is the coefficient of human capital stock relative to the total number of people, because the adoption of the law of education, so $\lambda=1 / \mathrm{P}, \mathrm{P}$ is the total population of the whole society.Lt said that the total number of social employment in the year t.So the expression (4) into (3), can easily get the entire human capital of the complete expression:

$$
H_{t}=e^{\lambda \Sigma H E i t \cdot h i} L_{t} \text { (i from } 1 \text { to 5) }
$$

Substituting (2) and (3) into (1) and taking the logarithm $\mathrm{m}$ to remove the heteroskedasticity and linearize the following expression: 
$\ln Y=\ln A+\alpha \beta \ln K D+\alpha(1-\beta) \ln F D I+(1-\alpha) \lambda H^{\prime}+(1-\alpha) \ln L$

According to (6), the following regression equation can be established:

$$
\ln Y_{t}=a_{0}+a_{1} \ln K D_{t}+a_{2} \ln F D I_{t}+a_{3} \lambda H^{\prime}+a_{4} \ln L_{t}+\mu t
$$

\subsection{Measurement methods and data}

This paper starts from the model of the whole country, analyzes the results of the regression from the national data, and then analyzes the three key provinces and cities in Jiangsu province. The following is a brief description of each variable:

(a) Gross Domestic Product (Y), expressed in millions of yuan, representing the total output of the region; (b) The total domestic capital (KD), the unit is billion yuan, because it is a stock concept, this article with domestic fixed asset investment to remove the investment from foreign investment part of the total domestic capital; (c) Foreign direct investment (FDI), the unit is RMB billion, the foreign direct investment of the original data is denominated in US dollars, according to the annual exchange rate of RMB against the US dollar into RMB; (d) The total amount of human capital in the whole society $\left(\lambda H^{\prime}\right)$ is divided by the number of years of education in the higher education, secondary vocational schools, high schools, junior high schools and primary schools in each region. The sum of the income is divided by the total population is the whole society of human capital stock level.The number of people involved in the number of people to get the statistics for a representative of the whole society of human capital stock level of statistics, the value of the natural number of about 1 hovering; (e) Labor force (L), the unit for the million, the use of the region at the end of the total number of employment to replace the labor force.

\section{Regression results and analysis}

The national data in accordance with the original model set, after the regression to get the following results:

Table 1 FDI and other factors on China, Jiangsu economic growth

\begin{tabular}{|c|c|c|c|c|c|c|c|}
\hline $\begin{array}{l}\text { variabl } \\
\text { e }\end{array}$ & 1.1 & 1.2 & 1.3 & 2.1 & 2.2 & 2.3 & 2.4 \\
\hline $\operatorname{lnKD}$ & $\begin{array}{l}0.469^{* *} \\
(2.45)\end{array}$ & & & & & & \\
\hline $\begin{array}{l}\operatorname{LnKD}(- \\
\text { 1) }\end{array}$ & & $\begin{array}{l}0.520^{* *} \\
(13.56)\end{array}$ & $\begin{array}{l}0.538^{* * *} \\
(12.43)\end{array}$ & $\begin{array}{l}0.568^{* *} \\
(10.82)\end{array}$ & $\begin{array}{l}0.582^{* *} \\
(10.12)\end{array}$ & $\begin{array}{l}0.576^{* *} \\
(11.20)\end{array}$ & $\begin{array}{l}0.613^{* *} \\
(11.22)\end{array}$ \\
\hline $\operatorname{lnFDI}$ & $\begin{array}{l}0.117^{* *} \\
(3.27)\end{array}$ & $\begin{array}{l}0.110^{* *} \\
(6.54)\end{array}$ & $\begin{array}{l}0.087^{* * *} \\
(2.84)\end{array}$ & $\begin{array}{l}0.083^{* *} \\
(4.17)\end{array}$ & $\begin{array}{l}0.075^{*} \\
(3.06)\end{array}$ & $\begin{array}{l}0.074^{* *} \\
(4.01)\end{array}$ & $\begin{array}{l}0.074^{* *} \\
(3.58)\end{array}$ \\
\hline $\ln \mathrm{L}$ & $\begin{array}{l}1.547^{* * *} \\
(3.58)\end{array}$ & $\begin{array}{l}1.285^{* *} \\
(6.54)\end{array}$ & $\begin{array}{l}1.295^{* * *} \\
(6.13)\end{array}$ & $\begin{array}{l}0.909^{* *} \\
(3.90)\end{array}$ & $\begin{array}{l}0.857^{* *} \\
(3.43)\end{array}$ & $\begin{array}{l}2.917^{* *} \\
(2.12)\end{array}$ & \\
\hline$\lambda \mathrm{H}^{\prime}$ & $\begin{array}{l}0.853^{* * *} \\
(2.45)\end{array}$ & $\begin{array}{l}0.662^{* *} \\
(4.15)\end{array}$ & $\begin{array}{l}0.609^{* * *} \\
(3.57)\end{array}$ & $\begin{array}{l}0.741^{* *} \\
(3.93)\end{array}$ & $\begin{array}{l}0.712^{* *} \\
(3.62)\end{array}$ & $\begin{array}{l}0.523^{* *} \\
{ }^{*}(2.71)\end{array}$ & $\begin{array}{l}0.640^{* *} \\
*(3.07)\end{array}$ \\
\hline C & $\begin{array}{l}- \\
12.752^{* *} \\
(-2.84)\end{array}$ & $\begin{array}{l}- \\
9.968^{* *} \\
(-4.55)\end{array}$ & $\begin{array}{l}- \\
10.052^{* *} \\
(-4.56)\end{array}$ & $\begin{array}{l}- \\
4.497^{* *} \\
(-2.33)\end{array}$ & $\begin{array}{l}-4.113^{*} \\
(-2.01)\end{array}$ & $\begin{array}{l}-2.109^{*} \\
(-1.86)\end{array}$ & $\begin{array}{l}2.961^{*} \\
(2.94)\end{array}$ \\
\hline C1 & & & $\begin{array}{l}0.052 \\
(0.90) \\
\end{array}$ & & $\begin{array}{l}0.037 \\
(0.66) \\
\end{array}$ & & \\
\hline Adj-R ${ }^{2}$ & 0.996 & 0.999 & 0.999 & 0.999 & 0.999 & 0.999 & 0.998 \\
\hline DW & 1.032 & 1.699 & 1.829 & 1.898 & 1.904 & 2.023 & 2.050 \\
\hline
\end{tabular}

Note: * indicates significant at $10 \%$ level, ** indicates significant at $5 \%$ level, ${ }^{* * *}$ indicates significant at $1 \%$ level.

First, the result of model 1.1, the national data in full accordance with the regression equation (7) after the regression, we can find that the whole regression of the high degree of fitting, $R$ value reached 0.99 , the explanatory variables of the coefficient values in line with economic significance, its $T$ value and $P$ value have passed the test, the only shortcoming is that the DW value is very small, the problem is due to the possible existence of autocorrelation problem.With the KD use of domestic fixed assets investment to get rid of foreign capital data to replace the domestic investment, Its own there is a lag effect, therefore, will KD lag a period of regression, it was 1.2 results.

The regression results are further optimized, and the trend of the explanatory variable coefficients is not changed, further indicating that the regression equation is stable.Through the analysis of GDP, KD and FDI data, you can find the data, including GDP and an increase trend before and after 2000. Therefore, consider introducing the dummy variable $\mathrm{C} 1$ with 2000 as the demarcation point, setting the value before 2000 to 0 , and setting the value after 2000 to 1 , Regression, you can get the results of model 1.3.

On the basis of the relevant data and conclusions of the national regression, the author applies the model to the empirical analysis of Jiangsu Province, and makes similar treatment to the data of Jiangsu. Verify that the above conclusions are in line with the situation in Jiangsu Province, the empirical return after Table 2 results: Model 2.1 is the result of the regression of $\mathrm{KD}$ for one period: the indicators are passed and the regression is very good. Consider the introduction of the dummy variable $\mathrm{C} 1$, whether the model can be optimized to get the results of model 2.2. But the conclusion is still consistent with the results of the same conditions in the country, that is to say, the 2000 trend segment can not be confirmed in the empirical analysis of this model.

Then the direct return to the 20-year data from 1997 to 2016 can have a new finding, and the results of Model 2.3 can be obtained. It is found that each variable coefficient is consistent with the national analytical conclusion.After the removal of the labor force, the 20 years of data regression, the author has got the results of model 2.4, the conclusion is still consistent with the pre-empirical analysis of the forecast, human capital and domestic capital of the economic pull is far greater than the direct pull of FDI.

\section{Conclusions}

(a)The regression results clearly show that the relative direct impact of FDI on the economy is much more pronounced. The direct effect of FDI on the economy is not obvious, which is consistent with the empirical results of many domestic scholars. (b)Even in individual provinces, the direct pull of domestic capital is 5 to 7 times higher than that of FDI. It should be said that the pulling of FDI to the economy not only solves the shortage of domestic savings and foreign exchange funds, but also has a wide range of mechanisms for economic development. (c)The domestic capital has a significant effect on the economy. (d)The pulling effect of the labor force is much higher than the human capital in the regression of this paper, and it is also higher than that of the domestic capital and FDI. This result is contradictory to the new economic growth theory.

\section{References}

[1] Ba lasubramanyam, V. N. , Salisu, M. and Sapsford, D. Foreign directive investment and growth in EP and IS countries[J]. The Economic Journal. 1996, 106:92-105.

[2] Boreasetein E, J De Gregorio, J Lee. How does Foreign Investment Affect Economics Growth [J]. Journal of International Economics, 1998(45):115135 .

[3] Laura Alfaro, Canada. Areendam, Kalemhi-Ozcan. Sebnem. Sayek. Selin, FDI and economic growth : the role of local financial markets[J]. Journal of International Economics, 2004(64):98-105.

[4] Shives, Makki and Agapi Somwap. Impact of directive investment and trade on economic growth: Evidence from developing countries [J]. Journal of America Agricultural Economic, 2004,8:795-801.

[5] Jinfan Jiang. The Mechanism of Foreign Direct Investment in China 's Economic Growth [J]. World Economic Journal, 2010(1).

[6] Wei Cao. An Empirical Analysis of the Impact of Foreign Direct Investment on China 's Economic Growth [J]. Journal of World Economic Study, 2005(8):39-43.

[7] Lifa Hu. An Empirical Analysis of the Contribution Rate of "Solo Surplus" and Foreign Investment to China 's Economic Growth [J]. Journal of World Economic Study, 2003(10):54-56.

[8] Yaxin Mao, Guixin, Wang. Capital Formation and Economic Growth Effect of Foreign Direct Investment in Yangtze River: Research on Panel Data Based on Panel [J]. Journal of World Economic Study, 2006(1):65-71. 